\title{
Phytochemical analysis and assessment of antioxidant, antimicrobial, anti- inflammatory and cytotoxic properties of Tetraclinis articulata (Vahl) Masters leaves
}

\author{
Wahiba Rached ${ }^{\mathrm{a}, \mathrm{b}, \mathrm{c}, \mathrm{d}}$, Fatima Zohra Zeghada ${ }^{\mathrm{b}, \mathrm{e}}$, Malika Bennaceur ${ }^{\mathrm{b}, \mathrm{e}}$, Lillian Barros $^{\mathrm{a}, *}$, \\ Ricardo C. Calhelha ${ }^{a}$, Sandrina Heleno ${ }^{a}$, Maria José Alves ${ }^{a}$, Ana Maria Carvalho ${ }^{a}$, \\ Abderrazak Maroufe, Isabel C.F.R. Ferreira ${ }^{\mathrm{a}, *}$

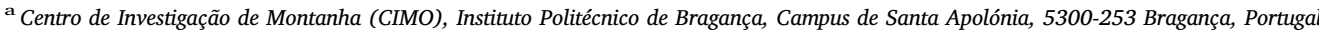 \\ b Laboratory of Plant Biochemistry and Natural Products, Department of Biology, Faculty of Nature and Life Sciences, University of Oran 1, Ahmed Ben Bella, 1524 EL M \\ Naouer, 31000 Oran, Algeria \\ ${ }^{\mathrm{c}}$ Department of Biology, Faculty of Nature and Life Sciences, University of Mostaganem, BP 188/227, Mostaganem 2700, Algeria \\ d Department of Nature and Life Sciences, Institute of Science and Technology, Center University Salhi Ahmed, BP 66, 45000 Naama, Algeria \\ ${ }^{\mathrm{e}}$ Laboratory of Researchin Arid Areas (LRZA), Faculty of Biological Sciences, PO Box 32, El Alia Bab-Ezzouar, Algiers 16111, Algeria
}

\section{A R T I C L E I N F O}

\section{Keywords:}

Tetraclinis articulata

Antioxidant

Anti-inflammatory

Antibacterial

Cytotoxicity

Phenolic compounds

\begin{abstract}
A B S T R A C T
Tetraclinis is an unexplored genus recognized for its great bioactive potential that could be explored as a medicinal herb. The aim of this study was to evaluate the antioxidant, antibacterial, anti-inflammatory and cytotoxic properties of the aqueous crude extract and subsequent organic fractions of the Algerian medicinal plant $T$. articulata. Moreover, polyphenols were also fully profiled by liquid chromatography with diode-array detection coupled to electrospray ionization in tandem with mass spectrometry (LC-DAD-ESI-MS ${ }^{\mathrm{n}}$ ). The analysis of the obtained results show that B-type (epi)catechin dimer and catechin were the most abundant phenolic compounds present among the nine different flavonoids identified such as: ((epi)catechin, myricetin, quercetin and kaempferol glycoside derivatives). The concentration of phenolic compounds in the ethyl acetate fraction (93.1 $\mathrm{mg} / \mathrm{g}$ extract) was higher than the one of the aqueous extract $(21.2 \mathrm{mg} / \mathrm{g}$ extract) and butanol fraction (43.87 mg/g extract). Furthermore, the ethyl acetate fraction revealed the strongest bioactive properties, revealing the lowest $\mathrm{EC}_{50} / \mathrm{GI}_{50}$ values: anti-inflammatory $\left(\mathrm{EC}_{50}, 129.67 \mu \mathrm{g} / \mathrm{mL}\right)$, cytotoxicity against human tumor cell lines $\left(\mathrm{GI}_{50}, 59-189 \mu \mathrm{g} / \mathrm{mL}\right.$ ), antibacterial (MIC, $0.625-10 \mathrm{mg} / \mathrm{mL}$ ); and especially the antioxidant capacity $\left(\mathrm{EC}_{50}\right.$ values lower than $12.7 \mu \mathrm{g} / \mathrm{mL}$ ), even higher than the standard (Trolox). The results showed a great bioactive potential for this species, with a significant contribution of flavonoid compounds, which makes it an interesting matrix in the development of novel pharmaceutical formulations.
\end{abstract}

\section{Introduction}

The diseases related with the oxidative stress, such as cancer and cardiovascular problems (Andrade et al., 2005; Azmi et al., 2006) has become a serious problem in recent years. Accordingly, natural antioxidant products obtained from medicinal herbs, such as phenolic compounds, vitamins and terpenoids have been widely applied in food and medicinal fields (Cai et al., 2004; Leandro et al., 2012; Sadiq, 2014). In particular, the antioxidant activity of polyphenols, mainly flavonoids, is related with free radical-scavenging capacity, strong linkage to free ferrous ions and antimutagenic effect through high inhibition of the oxidative DNA damage (Lodovici et al., 2001; Wu et al.,
2007). Hence, the antitumor capacity of these molecules is related to the induction of apoptosis, suppression of protein tyrosine kinase activity, antiproliferation, antimetastasis and anti-angiogenesis effects. In addition, flavonoids are able to inhibit the inflammation process in vivo and in vitro and also possess antibacterial, and antifungal activities (Barros et al., 2010; Carocho and Ferreira, 2013; Kanadaswami et al., 2005; Serafini et al., 2010).

Tetraclinis articulata (Vahl.) Masters (sandarac gum or thuya of Berberie) is a rich source of bioactive phytochemicals, being the only species that represents the Tetraclinis genus. It is an evergreen coniferous tree, endemic to the mountainous regions of North Africa which occurs in Morocco, Algeria and Tunisia, being also found in other parts

\footnotetext{
* Corresponding authors.

E-mail addresses: lillian@ipb.pt (L. Barros), iferreira@ipb.pt (I.C.F.R. Ferreira).
} 
of Europe such as Malta and Spain (near Cartagena) (Quezel and Santa, 1963). Different parts of this species from the Mediterranean Basin have been used in traditional medicine, due to the presence of several valuable bioactive molecules. The aerial parts (leaves and twigs) are mainly used in the treatment of intestinal, respiratory infections, gastric diseases, diabetes, hypertension and to treat rheumatism (Jouad et al., 2001). The two papery wings of T. articulata seeds are also used for diabetes, hypertension, as febrifuge, against vertigo and headache, and antidiarrheal (Ziyyat et al., 1997). The whole plant, including branches with leaves, fructifications (cones) and resins, have been used for skin diseases including pruritus, parasitosis, mycosis, insect bites and pathology of the oral sphere (Bourkhiss et al., 2007). The antimicrobial (Ben Ghnaya et al., 2016; Bourkhiss et al., 2007), antitumor and antiinflammatory activities of its essential oils have also been reported (Buhagiar et al., 1999; Djouahri et al., 2014). The most important potential is the antioxidant activity, which is directely related with the presence of phytochemical compounds, such as the essential oils in leaves (obtained by hydrodistillation extraction), and the polyphenols present in the extracts of the plant twigs obtained with water, ethanol, hexane, dichloromethane, ethyl acetate and methanol. The authors (Barrero et al., 2003; El Jemli et al., 2016; Herzi et al., 2013a; Rached et al., 2010; Zidane et al., 2014) also described the presence of other compounds in the leaves of T. articulata, such as pimaranes and pimarane diterpenoids. Most of the studies in T. articulata from Algeria have been focused on the essential oils, and to the authors best knowledge, there are no studies related to its phenolic composition.

The objectives of the present research were to: i) evaluate the bioactive properties of $T$. articulata leaves originated from Algeria (in the crude aqueous extract and corresponding fractions) especially: antioxidant, anti-inflammatory, antimicrobial and cytotoxic activities; and ii) determine the phenolic composition of the crude extract and subsequent fractions, in order to establish a relationship between the chemical composition and the exhibited bioactivity.

\section{Materials and methods}

\subsection{Plant material and extract preparation}

Leaves of Tetraclinis articulata (Vahl) Masters were collected in the West of Algeria (Oran) in September 2016. Marouf Abderrazak, Professor at the University centre of Naama, Algeria performed the Botanical identification confirmation. Afterwards, the samples were lyophilized and reduced to a fine dried powder ( $\sim 40$ mesh). The homogenous sample was kept, protected from light in a desiccator until further analysis.

The extract and correspondent fractions were obtained using a methodology previously described by the authors (Rached et al., 2016). The crude aqueous extract was obtained using a heat reflux with $10 \%$ $(\mathrm{w} / \mathrm{v})$ of plant, for $30 \mathrm{~min}$. After filtration, the extraction methodology was successively performed three more times. The extracts were further joint together and lyophilized (FreeZone 4.5 model 7750031, Labconco, Kansas City, MO, USA), to obtain a concentrated dried extract. In order to achieve the organic fraction, the crude aqueous extract was dissolved with distilled water $(10 \mathrm{~g} / 100 \mathrm{~mL})$ and a liquid-liquid partitioning extraction was performed using ethyl acetate and butanol, successively (using equal volume). The resulting fractions were filtered and evaporated under reduced pressure at $40{ }^{\circ} \mathrm{C}$, in order to obtain dry extracts.

\subsection{Phenolic compounds characterization}

Liquid chromatography with diode-array detection coupled to electrospray ionization in tandem with mass spectrometry (LC-DAD-ESI-MS $^{\mathrm{n}}$ ) (Dionex Ultimate 3000 UPLC, Thermo Scientific, San Jose, CA, USA) analysis was performed in order to obtain the phenolic compounds profile, as previously described by Bessada et al. (2016). The crude aqueous extract and the two organic fractions were dissolved at a concentration of $5 \mathrm{mg} / \mathrm{mL}$, in water and methanol, respectively. The compounds were detected by using a DAD (280 and $370 \mathrm{~nm}$ as preferred wavelengths) and a Linear Ion Trap LTQ XL mass spectrometer equipped with an ESI source (ThermoFinnigan, San Jose, CA, USA), operating in negative mode. Phenolic compound identification was performed by comparing compounds characteristics with commercial standards, and also, by using available data reported in the literature. Calibration curves were performed based on the UV-vis signal, using available phenolic standard (catechin; myricetin-3-O-glucoside; quercetin-3-O-glucoside, kaempferol-3-O-glucoside, all with HPLC purity $\geq 99 \%$, purchased from Extrasynthese, Genay Cedex, France). The results were expressed as $\mathrm{mg} / \mathrm{g}$ of extract.

\subsection{In vitro antioxidant activity assays}

The aqueous crud extract and the organic fractions were prepared at a concentration of $10 \mathrm{mg} / \mathrm{mL}$ in water and methanol, respectively. The successive dilutions were performed to obtain the working concentrations ranging from 2500 to $5 \mu \mathrm{g} / \mathrm{mL}$. The antioxidant activity was evaluated by the 2,2-diphenyl-1-picrylhydrazyl (DPPH) radicalscavenging activity, reducing power, inhibition of $\beta$-carotene bleaching and inhibition of lipid peroxidation in brain cell homogenates using procedures previously reported by Barros et al. (2013). Trolox was used as positive control.

DPPH radical-scavenging activity was evaluated by using an ELX800 microplate reader (Bio-Tek Instruments, Inc; Winooski, VT, USA), and calculated as a percentage of DPPH discolouration using the formula: $\left[\left(A_{D P P H}-A_{S}\right) / A_{D P P H}\right] \times 100$, where $A_{S}$ is the absorbance of the solution containing the sample at $515 \mathrm{~nm}$, and $A_{D P P H}$ is the absorbance of the DPPH solution. Reducing power was evaluated by the capacity to convert $\mathrm{Fe}^{3+}$ into $\mathrm{Fe}^{2+}$, measuring the absorbance at $690 \mathrm{~nm}$ in the microplate reader mentioned above. Inhibition of $\beta$ carotene bleaching was evaluated though the $\beta$-carotene/linoleate assay; the neutralization of linoleate free radicals avoids $\beta$-carotene bleaching, which is measured by the formula: $\beta$-carotene absorbance after $2 \mathrm{~h}$ of assay/initial absorbance $\times 100$. Lipid peroxidation inhibition in porcine (Sus scrofa) brain homogenates was evaluated by the decrease in thiobarbituric acid reactive substances (TBARS); the colour intensity of the malondialdehyde-thiobarbituric acid (MDA-TBA) was measured by its absorbance at $532 \mathrm{~nm}$; the inhibition ratio (\%) was calculated using the following formula: $[(\mathrm{A}-\mathrm{B}) / \mathrm{A}] \times 100 \%$, where $\mathrm{A}$ and $\mathrm{B}$ were the absorbance of the control and the sample solution, respectively.

\subsection{Anti-inflammatory activity}

The LPS-induced NO production by Murine macrophage (RAW 264.7) cell lines was determined as nitrite concentration in the culture medium according to the method previously described by Sobral et al. (2016). For that purpose, the crude aqueous extract and the two organic fractions were dissolved at a concentration of $8 \mathrm{mg} / \mathrm{mL}$ in water and the nitric oxide (NO) production was determined using the Griess Reagent System kit. Dexamethasone was used as a positive control.

\subsection{Cytotoxicity assays}

The crude aqueous extract and organic fractions $(8 \mathrm{mg} / \mathrm{mL}$ in water) were tested to evaluate the inhibitory growth activity of NCI-H460 (non-small cell lung cancer), HeLa (cervical carcinoma), HepG2 (hepatocellular carcinoma) cell lines, as also a non-tumor cells PLP2 (porcine liver primary cells), by using the sulforhodamine B assay. Ellipticine was used as positive control (Barros et al., 2013).

\subsection{The antimicrobial activity}

The crude aqueous extract and organic fraction $(20 \mathrm{mg} / \mathrm{mL}$ in 
water) were assayed following a procedure previously described by Svobodova et al. (2017). Ten different strains were tested, such as six Gram-negative bacteria (1- Pseudomonas aeruginosa isolated from expectoration, 2- Escherichia coli, 3- Escherichia coli spectrum extended producer of $\beta$-lactamases (ESBL), 4- Klebsiella pneumoniae and 5- Klebsiella pneumoniae, spectrum extended producer of $\beta$-lactamases (ESBL), and 6- Morganella morganii, all isolated from urine) and four Grampositive bacteria (7- Enterococcus faecalis isolated from urine, 8- Listeria monocytogenes isolated from cerebrospinal fluid, 9- MSSA: Methicillinsensitive Staphylococcus aureus isolated from wound exudate, and 10MRSA: methicillin-resistant $S$. aureus, isolated from expectoration). Amikacin, tobramycin, amoxicillin/clavulanic acid and gentamicin were used as positive controls for Gram-negative bacteria strains while ampicillin and linezolid were used for Gram-positive bacteria. The MICs (minimal inhibitory concentrations) were determined using the rapid colorimetric assay with $p$-iodonitrotetrazolium chloride (INT). The resistance profile of the Gram-negative and Gram-positive bacteria to different antibiotics (MIC values, $\mu \mathrm{g} / \mathrm{mL}$ ) has previously been reported (Svobodova et al., 2017).

\subsection{Statistical analysis}

Results are expressed as mean values and standard deviations (SD), as an outcome of the three repetitions of the samples and concentrations that were carried out in all the assays. One-way analysis of variance (ANOVA) followed by Tukey's HSD test $(p=0.05)$, were used to analyzed the results. Moreover, to determine significant differences with $\alpha=0.05$ between less than 3 samples, a Students $t$-test was applied. Analyses were carried out using IBM SPSS Statistics for Windows, version 23.0. (IBM Corp., Armonk, New York, USA).

\section{Results and discussion}

\subsection{Composition of T. articulata in phenolic compounds}

The phenolic profile of the crude aqueous extract and fractions of $T$. articulata leaves was recorded at 280 and $370 \mathrm{~nm}$. Fig. 1 shows a representative chromatographic profile obtained for the ethyl acetate fraction. The compounds characteristics, identities and quantification are presented in Table 1. The chromatographic separation allowed the elucidation of nine phenolic compounds, among them three flavan-3-ols (peaks 1-3) and six flavonols (peaks 4-9) (Table 1).

Compounds 2 and 3 were positively identified as $(+)$-catechin and (-)-epicatechin, respectively, according to their retention time, mass and UV-vis characteristics by comparison with commercial standards. Both these compounds were previously described in extracts of $T$. articulata twigs obtained by decoction (aqueous extract) and Soxhlet (ethyl acetate and methanolic extracts) (Zidane et al., 2014). Compound $1\left([\mathrm{M}-\mathrm{H}]^{-}\right.$at $\left.m / z 577\right)$ revealed a $\mathrm{MS}^{2}$ fragmentation pattern coherent with B-type (epi)catechin dimer. Characteristic product ions were observed at $m / z 451(-126 \mathrm{u}), 425(-152 \mathrm{u})$ and $407(-152$ to
$18 \mathrm{u}$ ), attributable to the HRF (heterocyclic ring fissions), RDA (RetroDiels-Alder) and further loss of water from an (epi)catechin unit, and at $m / z 289$ and 287, that could be associated to the fragments corresponding to the lower and upper (epi)catechin unit, respectively (Rached et al., 2016). To the authoŕs best knowledge this compound was not previously reported in T. articulata.

The flavonol glycoside derivatives identified were derived from myricetin ( $\lambda_{\max }$ around $354 \mathrm{~nm}$ and a MS ${ }^{2}$ fragment at $m / z 317$, peaks 4-7), quercetin ( $\lambda_{\max }$ around $350 \mathrm{~nm}$ and a $\mathrm{MS}^{2}$ fragment at $m / z 301$, peak 8) and kaempferol $\left(\lambda_{\max }\right.$ around $340 \mathrm{~nm}, \mathrm{MS}^{2}$ fragment at $m / z$ 285, peak 9) (Table 1). Compound $6\left([\mathrm{M}-\mathrm{H}]^{-}\right.$at $m / z$ 479) was assigned as myricetin-3-O-glucoside in comparison with a commercial standard. Compound $4\left([\mathrm{M}-\mathrm{H}]^{-}\right.$at $\left.m / z 611\right)$ released two $\mathrm{MS}^{2}$ fragments at $m / z 479\left([\mathrm{M}-\mathrm{H}-132]^{-}\right.$, loss pentosyl moiety) and $m / z 317$ ([M-H-162 $]^{-}$, loss hexosyl moiety), corresponding to myricetin. The fact that two $\mathrm{MS}^{2}$ fragments were released, suggested that the two sugars were positioned in different positions of the aglycone, thus being assigned as myricetin- $O$-pentosyl-O-hexoside. Compound $5\left([\mathrm{M}-\mathrm{H}]^{-}\right.$ at $m / z 625$ ) released a $\mathrm{MS}^{2}$ fragment at $m / z 317\left([\mathrm{M}-\mathrm{H}-308]^{-}\right.$, loss of a deoxyhexosyl-hexoside moiety). The presence of myricetin-3-O-glucoside may point to peak 5 being also a 3-O-rutinoside, thus it was assigned as myricetin-3-O-rutinoside. Both these compounds were not preset in the phenolic profile reported by Zidane et al. (2014).

The remaining compounds (peaks 7-9) presented $\mathrm{MS}^{2}$ fragments corresponding to the loss of rhamnosyl $(-146 \mathrm{mu})$ moieties from myricetin, quercein and kaempferol. These compounds were previously described in T. articulata twig extracts (Zidane et al., 2014), thus being assigned as myricetin-3-O-rhamnoside (myricitrin, peak 7), quercetin3-O-rhamnoside (quercitrin, peak 8) and kaempferol-3-O-rhamnoside (afzelin, peak 9).

The ethyl acetate fraction presented the statistically higher ( $\mathrm{p}<0.05$ ) phenolic compounds concentration $(93.1 \pm 0.9 \mathrm{mg} / \mathrm{g}$ of extract) compared with butanol fraction and crude aqueous extract (43.87 \pm 0.02 and $21.2 \pm 0.2 \mathrm{mg} / \mathrm{g}$, respectively).

The compounds flavan-3-ols were the predominant phenolic compounds in all the samples, accounting to an average of $71 \%$ of the phenolic composition, with B-type (epi)catechin dimer as the main compound in the butanol fraction and in the aqueous crude extract $(26.0 \pm 0.2$ and $8.7 \pm 0.6 \mathrm{mg} / \mathrm{g}$, respectively), while catechin was the most abundant compound in the ethyl acetate fraction $(40.59 \pm 0.01 \mathrm{mg} / \mathrm{g})$. Regarding flavonols, this class of phenolic compounds were present in an average of $29 \%$ of the total phenolic composition, with ethyl acetate fraction presenting the most considerable content $(31.4 \pm 0.1 \mathrm{mg} / \mathrm{g}$ of extract), statistically higher $(\mathrm{p}<0.05)$ than the butanol fraction and the crude aqueous extract with $9.18 \pm 0.04$ and $6.7 \pm 0.1 \mathrm{mg} / \mathrm{g}$ of extract, respectively, being myricetin-3-O-rhamnoside the main compound.

The total content of phenolic compounds (flavonoids), determined by chromatographic analysis showed similarity to those obtained by using the colorimetric assay Folin-Ciocalteu (El Jemli et al., 2016) in aqueous extracts obtained by infusion of $T$. articulata from Morocco.

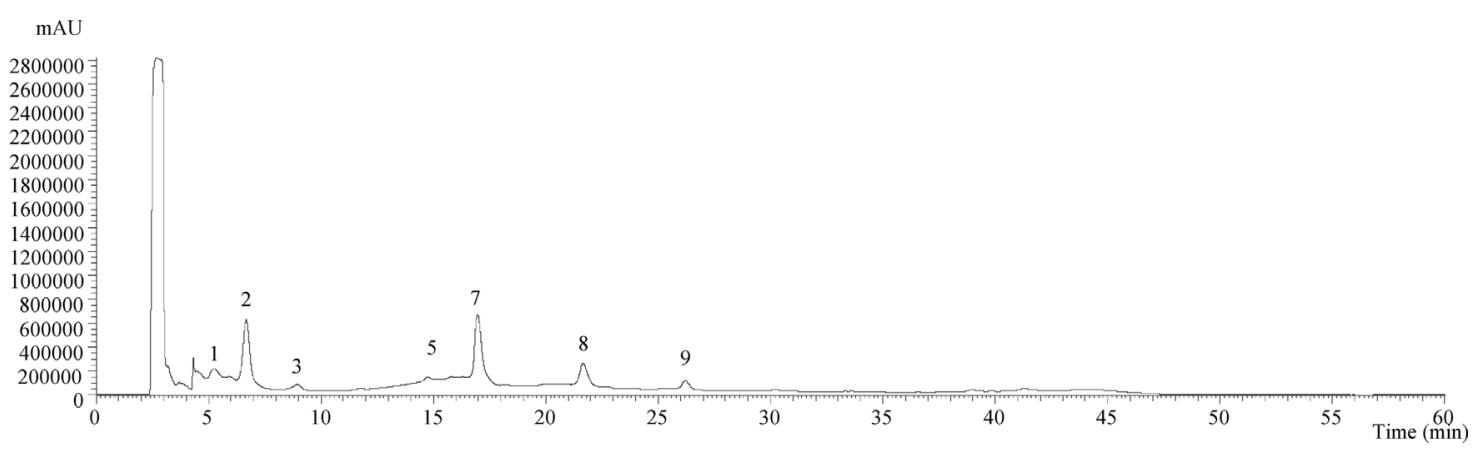

Fig. 1. Phenolic compounds profile of $T$. articulata ethyl acetate fraction, recorded at $280 \mathrm{~nm}$. Peak numbering corresponds to the molecules identified in Table 1. 
Table 1

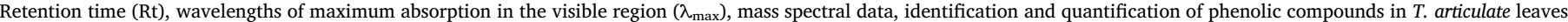
(mean $\pm \mathrm{SD}, \mathrm{n}=9$ ).

\begin{tabular}{|c|c|c|c|c|c|c|c|c|}
\hline \multirow[t]{2}{*}{ Peak } & \multirow[t]{2}{*}{ Rt (min) } & \multirow{2}{*}{$\begin{array}{l}\lambda_{\max } \\
(\mathrm{nm})\end{array}$} & \multirow{2}{*}{$\begin{array}{l}{[\mathrm{M}-\mathrm{H}]^{-}} \\
(m / z)\end{array}$} & \multirow[t]{2}{*}{$\operatorname{MS}^{2}(m / z)$} & \multirow[t]{2}{*}{ Identification } & \multicolumn{3}{|c|}{ Quantification (mg/g extract) } \\
\hline & & & & & & $\begin{array}{l}\text { Crude aqueous } \\
\text { extract }\end{array}$ & $\begin{array}{l}\text { Ethyl acetate } \\
\text { fraction }\end{array}$ & Butanol fraction \\
\hline 1 & 5.1 & 279 & 577 & 575()$, 451(25), 425(100), 407(21), 289(12), 287(9)$ & $\begin{array}{l}\text { B-type (Epi)catechin } \\
\text { dimer }^{\mathrm{A}}\end{array}$ & $8.7 \pm 0.6^{c}$ & $18.7 \pm 0.5^{\mathrm{b}}$ & $22.1 \pm 0.4^{\mathrm{a}}$ \\
\hline 2 & 6.7 & 280 & 289 & 245(100),231(8),205(33),179(11),165(5) & $(+)$-Catechin ${ }^{\mathrm{A}}$ & $5.69 \pm 0.02^{\mathrm{c}}$ & $40.59 \pm 0.01^{\mathrm{a}}$ & $8.6 \pm 0.3^{\mathrm{b}}$ \\
\hline 3 & 8.9 & 280 & 289 & 245(100),231(8), 205(33),179(12),165(3) & $(-)$-Epicatechin ${ }^{\mathrm{A}}$ & $\operatorname{tr}$ & $2.4 \pm 0.3^{*}$ & $3.9 \pm 0.1 *$ \\
\hline 4 & 12.6 & 355 & 611 & $479(100), 317(50)$ & $\begin{array}{l}\text { Myricetin- } O \text {-pentoxyl- } \\
O \text {-hexoside }\end{array}$ & $1.4 \pm 0.03^{*}$ & nd & $2.42 \pm 0.01 *$ \\
\hline 5 & 14.8 & 350 & 625 & $317(47)$ & $\begin{array}{l}\text { Myricetin-3-O- } \\
\text { rutinoside }^{B}\end{array}$ & $1.013 \pm 0.002^{\mathrm{b}}$ & $6.5 \pm 0.5^{\mathrm{a}}$ & $1.11 \pm 0.001^{\mathrm{b}}$ \\
\hline 6 & 14.7 & 352 & 479 & $301(100)$ & $\begin{array}{l}\text { Myricetin-3-O- } \\
\text { glucoside }^{B}\end{array}$ & $0.960 \pm 0.001^{*}$ & nd & $1.06 \pm 0.02^{*}$ \\
\hline 7 & 17.0 & 356 & 463 & $317(100)$ & $\begin{array}{l}\text { Myricetin-3-O- } \\
\text { rhamnoside }^{\mathrm{B}}\end{array}$ & $1.4 \pm 0.03^{\mathrm{c}}$ & $15.9 \pm 0.8^{\mathrm{a}}$ & $2.42 \pm 0.01^{\mathrm{b}}$ \\
\hline 8 & 21.7 & 352 & 447 & $301(100)$ & $\begin{array}{l}\text { Quercetin-3-O- } \\
\text { rhamnoside }^{\mathrm{C}}\end{array}$ & $1.013 \pm 0.002^{\mathrm{b}}$ & $6.5 \pm 0.5^{\mathrm{a}}$ & $1.106 \pm 0.003^{b}$ \\
\hline \multirow[t]{2}{*}{9} & 26.2 & 340 & 431 & $285(100)$ & $\begin{array}{l}\text { Kaempferol-3-O- } \\
\text { rhamnoside }^{\mathrm{D}}\end{array}$ & $0.961 \pm 0.001^{\mathrm{c}}$ & $2.43 \pm 0.02^{\mathrm{a}}$ & $1.06 \pm 0.02^{\mathrm{b}}$ \\
\hline & & & & & Total flavonoids & $21.2 \pm 0.2^{c}$ & $93.1 \pm 0.9^{\mathrm{a}}$ & $43.87 \pm 0.02^{b}$ \\
\hline
\end{tabular}

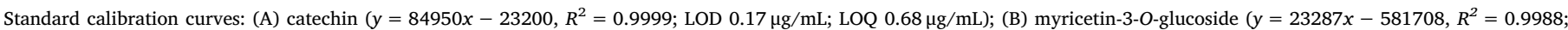

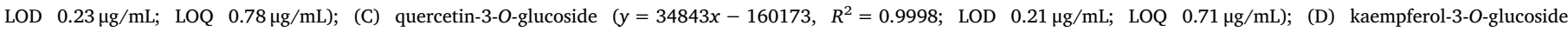

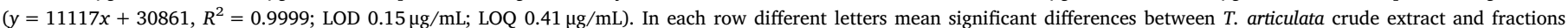

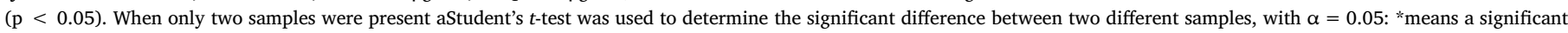
difference between the samples $(p>0.001)$.

The same was reported for the study of Herzi et al. (2013a, 2013b) which analyzed the ethanol and hexane extracts of $T$. articulata from Tunisia. Otherwise, Zidane et al. (2014) did not report the concentration of each compound present in T. articulata twig extracts, therefore it is not possible to make a comparison with the results obtained in the present study.

\subsection{Bioactive properties of T. articulata}

In the present work, four in vitro methods, following the previously mentioned mechanisms, were used to evaluate the antioxidant activity of T. articulata crude aqueous extract and its fractions. The Table 2 presents the results expressed as $\mathrm{EC}_{50}$ values of each one of the tested samples. For the DPPH assay, $\mathrm{EC}_{50}$ value of the ethyl acetate fraction

Table 2

Antioxidant activity and NO formation inhibition of T. articulata leaves (mean $\pm \mathrm{SD}$, $\mathrm{n}=9$ ).

\begin{tabular}{|c|c|c|c|c|}
\hline & $\begin{array}{l}\text { Crude aqueous } \\
\text { extract }\end{array}$ & $\begin{array}{l}\text { Ethyl acetate } \\
\text { fraction }\end{array}$ & $\begin{array}{l}\text { Butanol } \\
\text { fraction }\end{array}$ & $\begin{array}{l}\text { Positive } \\
\text { control }^{*}\end{array}$ \\
\hline \multicolumn{5}{|c|}{ Antioxidant activity $\left(E C_{50}\right.$ values, $\left.\mu \mathrm{g} / \mathrm{mL}\right)$} \\
\hline $\begin{array}{l}\text { DPPH scavenging } \\
\text { activity }\end{array}$ & $12.7 \pm 0.7^{\mathrm{a}}$ & $4.5 \pm 0.2^{c}$ & $8.7 \pm 0.2^{b}$ & $42 \pm 1$ \\
\hline Reducing power & $12.9 \pm 0.1^{\mathrm{a}}$ & $3.84 \pm 0.01^{\mathrm{c}}$ & $7.6 \pm 0.3^{\mathrm{b}}$ & $41 \pm 1$ \\
\hline $\begin{array}{l}\beta \text {-carotene } \\
\text { bleaching } \\
\text { inhibition }\end{array}$ & $1180 \pm 19^{b}$ & $779 \pm 52^{c}$ & $1236 \pm 8^{\mathrm{a}}$ & $18 \pm 1$ \\
\hline TBARS inhibition & $4.8 \pm 0.4^{\mathrm{a}}$ & $1.76 \pm 0.08^{\mathrm{b}}$ & $4.8 \pm 0.2^{\mathrm{a}}$ & $23 \pm 1$ \\
\hline \multicolumn{5}{|c|}{ Anti-inflammatory activity $\left(E C_{5 o}\right.$ values,$\left.\mu \mathrm{g} / \mathrm{mL}\right)$} \\
\hline $\begin{array}{l}\text { Nitric oxide }(\mathrm{NO}) \\
\text { production }\end{array}$ & $241 \pm 4^{a}$ & $130 \pm 9^{c}$ & $198 \pm 5^{b}$ & $16 \pm 1$ \\
\hline
\end{tabular}

* Trolox and dexamethasone for antioxidant and anti-inflammatory activities, respectively. The antioxidant activity was expressed as $\mathrm{EC}_{50}$ values (mean $\pm \mathrm{SD}$ ), what means that higher values correspond to lower reducing power or antioxidant potential. $\mathrm{EC}_{50}$ : extract concentration corresponding to $50 \%$ of antioxidant activity or 0.5 of absorbance in reducing power assay. Results of anti-inflammatory activity are expressed in $\mathrm{EC}_{50}$ values: sample concentration providing $50 \%$ of inhibition of nitric oxide (NO) production. In each row different letters mean significant differences between $T$. articulata and fractions $(\mathrm{p}<0.05)$.
(4.51 $\pm 0.15 \mu \mathrm{g} / \mathrm{mL})$ was observed to be statistically lower ( $\mathrm{p}<0.05)$, indicating a high antioxidant activity in comparison to other studied samples $\left(\mathrm{EC}_{50}\right.$ values: $8.65 \pm 0.16$ and $12.68 \pm 0.67 \mu \mathrm{g} / \mathrm{mL}$ for butanol fraction and aqueous extract, respectively). The ferric reducing ability of the present samples were similar to those obtained for the DPPH assay, where ethyl acetate fraction had the highest antioxidant capacity $\left(\mathrm{EC}_{50}=3.84 \pm 0.01 \mu \mathrm{g} / \mathrm{mL}\right)$, while the aqueous extract $\left(\mathrm{EC}_{50}=12.9 \pm 0.1 \mu \mathrm{g} / \mathrm{mL}\right)$ revealed statistically lower activity $(p<0.05)$. The antioxidant effects of various natural products are also measured using the $\beta$-carotene bleaching inhibition assay. Similarly, to the previous assays, the ethyl acetate fraction $\left(\mathrm{EC}_{50}=779 \pm 52 \mu \mathrm{g} / \mathrm{mL}\right)$ also exhibited the highest potential $(\mathrm{p}<0.05)$ in comparison to the other samples. The ethyl acetate fraction $\left(\mathrm{EC}_{50}=1.76 \pm 0.08 \mu \mathrm{g} / \mathrm{mL}\right)$ also presented the most significant inhibition $(\mathrm{p}<0.05)$ of lipid peroxidation using the thiobarbituric acid reactive substances (TBARS) assay. All the extracts in all the performed assays exhibited significantly antioxidant potential $(\mathrm{p}<0.05)$ when compared with Trolox, with the exception of the $\beta$ carotene bleaching inhibition assay.

In addition, the extracting solvent contributed to differences in the phenolic compounds concentration and profile in the studied extract and fractions. In fact, the identified phytochemicals have been previously reported as having an excellent effectiveness as antioxidants (Braca et al., 2002; Cimanga et al., 2001; Montoro et al., 2005; Srinivasan et al., 2015). Myricetin-3-O-rhamnoside, one of the main flavonols found in these samples, has been related to the antioxidant potential. For instance, this compound isolated from the leaves of Myrtus communis, exhibited a high capacity to inhibit xanthine oxidase activity, lipid peroxidation and to scavenge DPPH radicals (Hayder et al., 2008). Previous studies were also reported by El Jemli et al. (2016), that evaluated the antioxidant activity of the aqueous extract obtained from infusions of T. articulata leaves from Morocco, revealing activity when preforming the following assays: DPPH scavenging activity $(12.05 \pm 0.24 \mathrm{mg} / \mathrm{mL})$ and reducing power assay $(0.15 \pm 0.01 \mathrm{mg} / \mathrm{mL})$ which are less efficient when compared with the results obtained in the present study. In the same context, Herzi et al. (2013a, 2013b) also described DPPH scavenging potential for supercritical fluid extract (1000 bar) of $T$. articulata from Tunisia presenting 
an $\mathrm{EC}_{50}$ value of $108.16 \mu \mathrm{g} / \mathrm{mL}$. Djouahri and Boudarene, (2012) highlighted DPPH scavenging and reducing power activities for methanol crude extracts ( 28.55 and $0.5 \mathrm{mg} / \mathrm{mL}$ respectively) higher than ethyl acetate and chloroform extracts of T. articulata leaves collected from center western of Algeria. The observed activity is correlated with the phenolic compounds that play an important role as hydrogen donators and antioxidant scavengers.

The aqueous extract of $T$. articulata and its organic fractions showed a significant inhibition of NO production (Table 2). These results are in accordance with the traditional uses of this plant species, which has been used to cure inflammatory affections. The ethyl acetate fraction $\left(\mathrm{EC}_{50}=130 \pm 9 \mu \mathrm{g} / \mathrm{mL}\right)$ exhibited a higher effect $(\mathrm{p}<0.05)$ than the crude aqueous extract and butanol fraction. There are few studies that report the anti-inflammatory activity of this species, namely the ethyl acetate (79\%) and methanolic crude extracts (87\%) of $T$. articulata that have been described as having strong anti-inflammatory capacity, with a higher effect than allopurinol (75\%; reference substance) at $50 \mu \mathrm{g}$ / $\mathrm{mL}$, through the inhibition of lipooxygenase and xanthine oxidase (Djouahri and Boudarene, 2012). The results obtained in the present work, suggest that the anti-inflammatory potential could be correlated to the richness of this plant in flavonoids (catechin, epicatechin, myricetin-3-O-rhamnoside and quercetine-3-O-rhamnoside, the main compounds present in all samples). Hämäläinen et al. (2007) and Murakami et al. (2015), demonstrated a slight potential of catechin and epicatechin on the LPS-induced NO production in J774 cells and by using RAW264.7 cells stimulating Pg-fimbriaein and the inhibition of Cox2 and Tnfa gene expression respectively. In general, these compounds are anti-inflammatory molecules that could help to increase the organism capacity in the protection against inflammation, induced by oxidative stress. The antioxidant capacity demonstrated by the crude aqueous extract and fractions may be responsible for its anti-inflammatory potential, through reactive oxygen species scavenging.

With respect to the cytotoxicity effects, four human tumor cell lines (NCI-H460, MCF-7, HepG2 and HeLa) and a porcine liver cells primary culture (PLP2, non-tumor cells), were used. The aqueous extract of $T$. articulata and its fractions, demonstrated a good inhibitory potential against all the tumor cell lines, with different behaviors (Table 3). The lowest $\mathrm{GI}_{50}$ value (concentration of the extract causing $50 \%$ of cell growth inhibition), was obtained for the ethyl acetate fraction ( $p<0.05$ ), which could also be related to its highest content of flavan3-ols and flavonols. Kampa et al. (2000) demonstrated that catechin, epicatechin and quercetin had a good effect on the proliferation inhibition of three different human prostate cancer cell lines (LNCaP, PC3, and DU145). Moreover, flavonol rhamnosides have also been known to display a remarkable cytotoxic activity, inhibiting the proliferation of cultured human tumor cell lines, A549 (non-small cell lung), SK-OV-3 (ovary), SK-MEL-2 (skin), XF498 (central nerve system) and HCT-15 (colon) (Kim et al., 2004). The variation in flavonoids content and composition between the crude aqueous extract and its fractions could explain the differences observed in the cytotoxicity results, which is in agreement with other studies (Chaudhary et al., 2015;
Table 4

Antibacterial activity of $T$. articulata leaves (mean $\pm \mathrm{SD}, \mathrm{n}=9$ ).

\begin{tabular}{llll}
\hline Bacterial Strains & $\begin{array}{l}\text { Crude aqueous } \\
\text { extract }\end{array}$ & $\begin{array}{l}\text { Ethyl acetate } \\
\text { fraction }\end{array}$ & $\begin{array}{l}\text { Butanol } \\
\text { fraction }\end{array}$ \\
\hline $\begin{array}{l}\text { Gram-positive bactéria (MIC, mg/mL) } \\
\text { Enterococcus faecalis }\end{array}$ & 10 & 5 & \\
Listeria monocytogenes & 10 & 5 & 10 \\
MSSA & 1.25 & 0.625 & 10 \\
MRSA & 1.25 & 0.625 & 1.25 \\
Gram-negative bacteria (MIC, mg/mL) & & 1.25 \\
Eschericia coli & 10 & 5 & \\
E. coli ESBL & 10 & 5 & 10 \\
Klebsiella pneumoniae & 10 & 5 & 10 \\
K. pneumoniae ESBL & 10 & 5 & 10 \\
Morganella morganii & 20 & 10 & 10 \\
Pseudomonas aeruginosa & 20 & 10 & 10 \\
\end{tabular}

MRSA- Methicillin resistant Staphylococcus aureus; MSSA methicillin susceptible S. aureus; MIC- minimal inhibitory concentration; MBC- minimal bactericidal concentration; ESBLspectrum extended producer of $\beta$ - lactamases.

Rached et al., 2017, 2016). To the author's best knowledge, there are no previous reports on the cytotoxic effects of the studied plant.

The results of the antimicrobial activity of the crude aqueous extract and organic fractions of T. articulata leaves against the tested pathogenic microorganisms are presented in Table 4. The plant T. articulata leaves have been used in ethnomedicine to cure infectious diseases and the confirmation of its uses can be established due to its good activity against the selected bacteria strains. The ethyl acetate fraction exhibited a higher activity against all the tested bacterial strains, with the exception of $M$. morganii and $P$. aeruginosa, which revealed a similar activity to the butanol fraction (MIC $=10 \mathrm{mg} / \mathrm{mL}$ ). Although, ethyl acetate fraction exhibited a high inhibitory activity against MRSA and MSSA with a MIC of $0.625 \mathrm{mg} / \mathrm{mL}$, the crude aqueous extract and its butanol fraction also exhibited strong activity against these bacteria (MIC $=1.25 \mathrm{mg} / \mathrm{mL}$ ) when compared with other strains. The efficiency of these extracts against the pathogen microorganism strains could be due to their phenolic composition. Indeed, many research works have demonstrated that plant flavonols can act against several pathogens bacterial growth inhibition, highlight that these compounds are very well known for their bactericidal and bacteriostatic activities (Ahmad et al., 2015). Moreover, the identified phenolic compounds in the ethyl acetate fraction could be considered as potential antimicrobial agents. Flavonoids' mechanism of action against microorganisms is well described in literature and have been represented on the cytoplasmic membrane damage; energy metabolism inhibitory effect and nucleic acids synthesis inhibition (Ahmad et al., 2015; Dzoyem et al., 2013). Nevertheless, most of the natural compounds derived from plants exert their antibacterial activity on the microorganism (bacteria, fungi) cell wall (Zida et al., 2016). However, Caturla et al. (2003) demonstrated that catechins (catechin and epicatechin) shown leakage from liposomes composed from bacterial model membranes of $E$. coli

Table 3

Cytotoxic properties of T. articulata leaves in human tumor cell lines and non-tumor liver primary cells (mean $\pm S D, n=9$ ).

\begin{tabular}{|c|c|c|c|c|}
\hline & Crude aqueous extract & Ethyl acetate fraction & Butanol fraction & Ellipticine \\
\hline \multicolumn{5}{|l|}{ Human tumor cell lines ( $\left(\mathrm{I}_{50}\right.$ values, $\mu \mathrm{g} / \mathrm{mL}$ ) } \\
\hline MCF-7 (breast carcinoma) & $203 \pm 7^{\mathrm{a}}$ & $114 \pm 6^{c}$ & $153 \pm 7^{\mathrm{b}}$ & $0.91 \pm 0.04$ \\
\hline NCI-H460 (non-small cell lung cancer) & $200 \pm 15^{\mathrm{a}}$ & $189 \pm 7^{b}$ & $209 \pm 15^{\mathrm{a}}$ & $1.03 \pm 0.09$ \\
\hline HeLa (cervical carcinoma) & $98 \pm 8^{\mathrm{a}}$ & $59 \pm 3^{c}$ & $76 \pm 4^{b}$ & $1.91 \pm 0.06$ \\
\hline HepG2 (hepatocellular carcinoma) & $307 \pm 27^{\mathrm{a}}$ & $82 \pm 6^{\mathrm{c}}$ & $99 \pm 4^{\mathrm{b}}$ & $1.1 \pm 0.2$ \\
\hline \multicolumn{5}{|l|}{ Non-tumor cells (GI ${ }_{50}$ values, $\mu \mathrm{g} / \mathrm{mL}$ ) } \\
\hline PLP2 (porcine liver primary cells) & $>400$ & $205 \pm 8^{*}$ & $335 \pm 19^{*}$ & $3.2 \pm 0.7$ \\
\hline
\end{tabular}

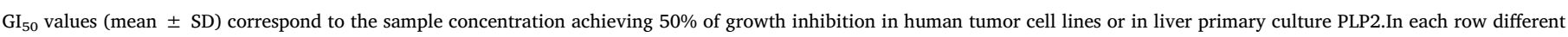

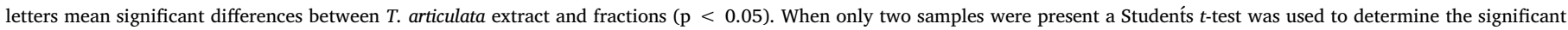
difference between two different samples, with $\alpha=0.05$ : *means a significant difference between the samples $(p>0.001)$. 
encapsulating the fluorescent probe carboxyfluorescein and detected the perturbation of bacterial membranes by those catechins. Chan et al. (2014) found that flavonol rhamnoside derivatives isolated from leaves of Calliandra tergemina (L.) Benth. showed antibacterial activities against MRSA. Similarly, Aderogba et al. (2013) showed a high antibacterial activity for myricetin-O-rhamnoside and quercetin-O-rhamnoside isolated from the leaves of Croton menyharthii Pax against $E$. coli, $K$. pneumonia and $S$. aureus and also described that the ethyl acetate fraction was more effective than a crude aqueous extract and a butanol fraction, which is in agreement with the results obtained inhere. In a previous study, Djouahri et al. (2014) showed that T. articulata cones methanolic, ethanolic and aqueous extracts, revealed an efficient potential against the six tested strains (Salmonella enterica, Klebsiella pneumoniae, Listeria monocytogenes, Staphylococcus aureus, Pseudomonas aeruginosa and Escherichia coli) and the MICs values ranged between 10 and $55 \mu \mathrm{g} / \mathrm{mL}$. The differences observed are due to the fact that the microorganism used in the present study are clinical isolates, that present a high resistance to several clinical used antibiotics. Another reason for the differences observed might also be due to the dissimilarity in the chemical composition among the various parts of the plant.

Overall, this study suggests that the aqueous crude extract of Algerian T. articulata leaves and its fractions possess antioxidant capacity, being more pronounced for the TBARS inhibition, and anti-inflammatory activity. Its cytotoxic property was more active against HeLa cell line, while for the antibacterial assay, the Gram-positive bacteria were more efficiently inhibited, thus, confirming its uses in traditional medicine for these purposes. The results also revealed that the studied samples are an excellent sources of bioactive substances including flavan-3-ols and flavonols, which can be related with the studied bioactivities. This work clarify that the leaves of this species should exploited in food and medicine as source of natural product, that have the potential to replace synthetic additive that present harmful effects. It can also be considered a good source of novel bioactive compounds with interesting health-promoting benefits, making it an active alternative ingredient used in pharmaceutical, food and cosmeceutical industries.

\section{Acknowledgments}

The authors are grateful to the Foundation for Science and Technology (FCT, Portugal) and FEDER under Program PT2020 for financial support to CIMO (UID/AGR/00690/2013), L. Barros and R. Calhelha contracts and S. Heleno (SFRH/BPD/101413/2014) grant. A greatly acknowledge also expressed to the MESRS of Algeria for the financial support that allowed to achieve the internship period at the IPB in the PNE program. The authors are also grateful to FEDERInterreg España-Portugal for financial support through the project 0377_Iberphenol_6_E.

\section{References}

Aderogba, M.A., Ndhlala, A.R., Rengasamy, K.R.R., Van Staden, J., 2013. Antimicrobial and selected in vitro enzyme inhibitory effects of leaf extracts, flavonols and indole alkaloids isolated from Croton menyharthii. Molecules 18, 12633-12644.

Ahmad, A., Kaleem, M., Ahmed, Z., Shafiq, H., 2015. Therapeutic potential of flavonoids and their mechanism of action against microbial and viral infections-a review. Food Res. Int. 77, 221-235.

Andrade, R.G., Dalvi, L.T., Silva, J.M.C., Lopes, G.K.B., Alonso, A., Hermes-Lima, M., 2005. The antioxidant effect of tannic acid on the in vitro copper-mediated formation of free radicals. Arch. Biochem. Biophys. 437, 1-9.

Azmi, A.S., Bhat, S.H., Hanif, S., Hadi, S.M., 2006. Ascorbic acid mobilizes endogenous copper in human peripheral lymphocytes leading to oxidative DNA breakage: a putative mechanism for anticancer properties. FEBS Lett. 580, 533-538.

Barrero, A.F., Quílez del Moral, J.F., Lucas, R., Payá, M., Akssira, M., Akaad, S., Mellouki, F., 2003. Diterpenoids from Tetraclinis articulata that inhibit various human leukocyte functions. J. Nat. Prod. 66, 844-850.

Barros, L., Carvalho, A.M., Ferreira, I.C.F.R., 2010. Leaves, flowers, immature fruits and leafy flowered stems of Malva sylvestris: a comparative study of the nutraceutical potential and composition. Food Chem. Toxicol. 48, 1466-1472.
Barros, L., Pereira, E., Calhelha, R.C., Dueñas, M., Carvalho, A.M., Santos-Buelga, C., Ferreira, I.C.F.R., 2013. Bioactivity and chemical characterization in hydrophilic and lipophilic compounds of Chenopodium ambrosioides L. J. Funct. Foods 5, 1732-1740.

Ben Ghnaya, A., Amri, I., Hanana, M., Gargouri, S., Jamoussi, B., Romane, A., Hamrouni, L., 2016. Tetraclinis articulata (Vahl.) masters essential oil from Tunisia: chemical characterization and herbicidal and antifungal activities assessment. Ind. Crops Prod. 83, 113-117.

Bessada, S.M.F., Barreira, J.C.M., Barros, L., Ferreira, I.C.F.R., Oliveira, M.B.P.P., 2016. Phenolic profile and antioxidant activity of Coleostephus myconis (L.) Rchb.f.: an underexploited and highly disseminated species. Ind. Crops Prod. 89, 45-51.

Bourkhiss, M., Hnach, M., Bourkhiss, B., Chaouch, M.O.A., 2007. Composition chimique et propriétés antimicrobiennes de l'huile essentielle extraite des feuilles de Tetraclinis articulata (Vahl) du Maroc. Afr. Sci. 3, 232-242.

Braca, A., Sortino, C., Politi, M., Morelli, I., Mendez, J., 2002. Antioxidant activity of flavonoids from Licania licaniaeflora. J. Ethnopharmacol. 79, 379-381.

Buhagiar, J.A., Podesta, M.T., Wilson, A.P., Micallef, M.J., Ali, S., 1999. The induction of apoptosis in human melanoma, breast and ovarian cancer cell lines using an essential oil extract from the conifer Tetraclinis articulata. Anticancer Res. 19, 5435-5443.

Cai, Y., Luo, Q., Sun, M., Corke, H., 2004. Antioxidant activity and phenolic compounds of 112 traditional Chinese medicinal plants associated with anticancer. Life Sci. 74, 2157-2184.

Carocho, M., Ferreira, I.C.F.R., 2013. The role of phenolic compounds in the fight against cancer - a review. Anticancer Agents Med. Chem. 13, 1236-1258.

Caturla, N., Vera-Samper, E., Villalaín, J., Mateo, C.R., Micol, V., 2003. The relationship between the antioxidant and the antibacterial properties of galloylated catechins and the structure of phospholipid model membranes. Free Radic. Biol. Med. 34, 648-662.

Chan, E.W.L., Gray, A.I., Igoli, J.O., Lee, S.M., Goh, J.K., 2014. Galloylated flavonol rhamnosides from the leaves of Calliandra tergemina with antibacterial activity against methicillin-resistant Staphylococcus aureus (MRSA). Phytochemistry 107, $148-154$.

Chaudhary, S., Chandrashekar, K.S., Pai, K.S.R., Setty, M.M., Devkar, R.A., Reddy, N.D., Shoja, M.H., 2015. Evaluation of antioxidant and anticancer activity of extract and fractions of Nardostachys jatamansi DC in breast carcinoma. BMC Compl. Altern. Med. 15, 50.

Cimanga, K., Ying, L., De Bruyne, T., Apers, S., Cos, P., Hermans, N., Bakana, P., Tona, L., Kambu, K., Kalenda, D.T., Pieters, L., Vanden Berghe, D., Vlietinck, A.J., 2001. Radical scavenging and xanthine oxidase inhibitory activity of phenolic compounds from Bridelia ferruginea stem bark. J. Pharm. Pharmacol. 53, 757-761.

Djouahri, A., Boudarene, L., 2012. Antioxidant and anti-inflammatory activity of methanolic: chloroform and ethyl acetate extracts of leaves Tetraclinis articulata (Vahl) Masters Algerian. Int. J. Res. Pharmacol. Pharmacother. 2, 7-11.

Djouahri, A., Saka, B., Boudarene, L., Benseradj, F., Aberrane, S., Aitmoussa, S., Chelghoum, C., Lamari, L., Sabaou, N., Baaliouamer, A., 2014. In vitro synergistic/ antagonistic antibacterial and anti-inflammatory effect of various extracts/essential oil from cones of Tetraclinis articulata (Vahl) masters with antibiotic and anti-inflammatory agents. Ind. Crops Prod. 56, 60-66.

Dzoyem, J.P., Hamamoto, H., Ngameni, B., Ngadjui, B.T., Sekimizu, K., 2013. Antimicrobial action mechanism of flavonoids from Dorstenia species. Drug Discov. Ther. 7, 66-72.

El Jemli, M., Kamal, R., Marmouzi, I., Zerrouki, A., Cherrah, Y., Alaoui, K., 2016. Radicalscavenging activity and ferric reducing ability of Juniperus thurifera (L.), J. oxycedrus (L.), J. phoenicea (L.) and Tetraclinis articulata (L.). Adv. Pharmacol. Sci. 6392656.

Hämäläinen, M., Nieminen, R., Vuorela, P., Heinonen, M., Moilanen, E., 2007. Anti-inflammatory effects of flavonoids: genistein, kaempferol, quercetin, and daidzein inhibit STAT-1 and NF-kB activations, whereas flavone, isorhamnetin, naringenin, and pelargonidin inhibit only NF-kB activation along with their inhibitory effect on iNOS expression and NO production in activated macrophages. Mediat. Inflamm. 2007, 45673.

Hayder, N., Bouhlel, I., Skandrani, I., Kadri, M., Steiman, R., Guiraud, P., Mariotte, A.M., Ghedira, K., Dijoux-Franca, M.G., Chekir-Ghedira, L., 2008. In vitro antioxidant and antigenotoxic potentials of myricetin-3-o-galactoside and myricetin-3-o-rhamnoside from Myrtus communis: modulation of expression of genes involved in cell defence system using cDNA microarray. Toxicol. Vitr. 22, 567-581.

Herzi, N., Bouajila, J., Camy, S., Romdhane, M., Condoret, J.S., 2013a. Comparison of different methods for extraction from Tetraclinis articulata: yield, chemical composition and antioxidant activity. Food Chem. 141, 3537-3545.

Herzi, N., Camy, S., Bouajila, J., Destrac, P., Romdhane, M., Condoret, J.-S., 2013b. Supercritical CO 2 extraction of Tetraclinis articulata: Chemical composition, antioxidant activity and mathematical modeling. J. Supercrit. Fluids 82, 72-82.

Jouad, H., Haloui, M., Rhiouani, H., El Hilaly, J., Eddouks, M., 2001. Ethnobotanical survey of medicinal plants used for the treatment of diabetes, cardiac and renal diseases in the North centre region of Morocco (Fez-Boulemane). J. Ethnopharmacol. 77, 175-182.

Kampa, M., Hatzoglou, A., Notas, G., Damianaki, A., Gemetzi, C., Kouroumalis, E., Martin, P., Castanas, E., Kampa, M., Hatzoglou, A., Notas, G., Damianaki, A., Bakogeorgou, E., Kampa, M., Hatzoglou, A., Notas, G., Damianaki, A., Bakogeorgou, E., Gemetzi, C., Kouroumalis, E., Martin, P., Castanas, E., 2000. Wine antioxidant polyphenols inhibit the proliferation of human prostate cancer cell lines. Nutr. Cancer 37, 223-233.

Kanadaswami, C., Lee, L.T., Lee, P.P.H., Hwang, J.J., Ke, F.C., Huang, Y.T., Lee, M.T., 2005. The antitumor activities of flavonoids. In Vivo (Brooklyn) 19, 895-910.

Kim, Y.-K., Kim, Y., Choi, S., Ryu, S., 2004. Isolation of flavonol rhamnosides from Loranthus tanakae and cytotoxic effect of them on human tumor cell lines. Arch. Pharm. Res. 27, 44-47.

Leandro, L.M., De Sousa Vargas, F., Barbosa, P.C.S., Neves, J.K.O., Da Silva, J.A., Da Veiga-Junior, V.F., 2012. Chemistry and biological activities of terpenoids from copaiba (Copaifera spp.) oleoresins. Molecules 17, 3866-3889. 
Lodovici, M., Guglielmi, F., Casalini, C., Meoni, M., Cheynier, V., Dolara, P., 2001. Antioxidant and radical scavenging properties in vitro of polyphenolic extracts from red wine. Eur. J. Nutr. 40, 74-77.

Montoro, P., Braca, A., Pizza, C., De Tommasi, N., 2005. Structure-antioxidant activity relationships of flavonoids isolated from different plant species. Food Chem. 92, 349-355.

Murakami, Y., Kawata, A., Ito, S., Katayama, T., Fujisawa, S., 2015. Radical-scavenging and anti-inflammatory activity of quercetin and related compounds and their combinations against RAW264.7 cells stimulated with Porphyromonas gingivalis Fimbriae. relationships between anti-inflammatory activity and quantum chemical par. In Vivo (Brooklyn) 29, 701-710.

Quezel, P., Santa, S., 1963. Nouvelle flore de l'Algérie.

Rached, W., Benamar, H., Bennaceur, M., Marouf, A., 2010. Screening of the antioxidant potential of some algerian indigenous plants. J. Biol. Sci. 10, 316-324.

Rached, W., Calhelha, R.C., Fernandes, Â., Carvalho, A.M., Bennaceur, M., Marouf, A. Barros, L., Santos-Buelga, C., Ferreira, I.C.F.R., Acquaviva, A., Bilotto, S., Russo, G.L., 2016. Phytochemical characterization and bioactive properties of Osyris quadripartita Salzm. ex Decne. leaves from Algeria. RSC Adv. 6, 72768-72776.

Rached, W., Bennaceur, M., Barros, L., Calhelha, R.C., Heleno, S.A., Alves, M.J., Carvalho, A.M., Marouf, A., Ferreira, I.C.F.R., 2017. Detailed phytochemical characterization and bioactive properties of Myrtus nivelii Batt \& Trab. Food Funct. 8, 3111-3119.

Sadiq, A., 2014. Qualitative and quantitative determination of secondary metabolites and antioxidant potential of Eruca sativa. Nat. Prod. Chem. Res. 2, 1-7.

Serafini, M., Peluso, I., Raguzzini, A., 2010. Flavonoids as anti-inflammatory agents. Proc.
Nutr. Soc. 69, 273-278

Sobral, F., Sampaio, A., Falcão, S., Queiroz, M.J.R.P., Calhelha, R.C., Vilas-Boas, M., Ferreira, I.C.F.R., 2016. Chemical characterization, antioxidant, anti-inflammatory and cytotoxic properties of bee venom collected in Northeast Portugal. Food Chem. Toxicol. 94, 172-177.

Srinivasan, R., Natarajan, D., Shivakumar, M.S., 2015. Antioxidant Compound Quercetin3-O- $\alpha$-L-rhamnoside $(1 \rightarrow 6)$ - $\beta$-D-glucose (Rutin) isolated from ethyl acetate leaf extracts of Memecylon edule Roxb (Melastamataceae). Free Radic. Antioxid. 5, 35-42.

Svobodova, B., Barros, L., Calhelha, R.C., Heleno, S., Alves, M.J., Walcott, S., Bittova, M. Kuban, V., Ferreira, I.C.F.R., 2017. Bioactive properties and phenolic profile of Momordica charantia L. medicinal plant growing wild in Trinidad and Tobago. Ind. Crops Prod. 95, 365-373.

Wu, Q., Yang, Y., Simon, J.E., 2007. Qualitative and quantitative HPLC/MS determination of proanthocyanidins in Areca Nut (Areca catechu). Chem. Biodivers. 4, 2817-2826.

Zida, A., Bamba, S., Yacouba, A., Guiguemdé, R.T., 2016. GENERAL REVIEW/REVUE GE anti-Candida albicans natural products, sources of new antifungal drugs: a review. J. Mycol. Med. 40.

Zidane, A., Tits, M., Angenot, L., Wauters, J.N., Frederich, M., Dib, I., Mekhfi, H., Aziz, M., Bnouham, M., Legssyer, A., Ziyyat, A., 2014. Phytochemical analysis of Tetraclinis articula in relation to its vasorelaxant property. J. Mater. Environ. Sci. 5, 1368-1375.

Ziyyat, A., Legssyer, A., Mekhfi, H., Dassouli, A., Serhrouchni, M., Benjelloun, W., 1997. Phytotherapy oh hypertension and diabetes in oriental Morocco. J. Ethnopharmacol. 58, 45-54. 